\title{
Organometallic Derivatives of Ruthenium (II \& III) ligated by Quinazole-2-thione-4-one
}

\author{
R.N. PANDEY* and K.V. GAUTAM \\ P.G. Centre of Chemistry (M.U.), College of Commerce, Patna - 800 020, India. \\ ${ }^{\star}$ Corresponding author E-mail : rameshwarnath.pandey@yahoo.com, kirtivardhangautam@gmail.com \\ http://dx.doi.org/10.13005/ojc/300152 \\ (Received: February 02, 2014; Accepted: March 07, 2014)

\begin{abstract}
Mixed ligand phosphine and arsine complexes of ruthenium (II \& III) ligated by Quinazole-2thione-4-one $(\mathrm{QTH})$ of composition $\left[\mathrm{Ru}\left(\mathrm{P} \phi_{3}\right)_{2}(\mathrm{QT})_{2}\right]$, $\left[\mathrm{RuX}(\mathrm{CO})\left(\mathrm{E} \phi_{3}\right)_{2}(\mathrm{QT})\right]$ and $\left[\mathrm{RuX}\left(\mathrm{E}_{3}\right)_{2}(\mathrm{QT})\right](\mathrm{E}$ $=\mathrm{P} / \mathrm{As} ; \mathrm{X}=\mathrm{Cl} / \mathrm{Br} ; \mathrm{QT}=$ monobasic bidentate $\mathrm{N}, \mathrm{S}$-chelating ligand) are prepared and investigated. The identities of complexes are established by elemental analysis, conductivity measurements, magnetic susceptibility and spectral methods (IR, UV-vis, ${ }^{1} \mathrm{H}$ NMR). An octahedral geometry has been tentatively proposed for all these complexes.
\end{abstract}

Key words: Ruthenium (II \& III) chelates, Heterocyclic Thioamide, Octahedral.

\section{INTRODUCTION}

Quinazole-2-thione-4-one (Str. I) contains amide and thioamide groups having interesting donor sites. ${ }^{1}$ We have reported some complexes of low-valent ${ }^{2}$ and high-valent ${ }^{3}$ metal ions with this ligand in our earlier communication. The present paper reports synthesis, spectral characterization and structural investigation of some ruthenium (II \& III) chelates with this ligand.

\section{EXPERIMENTAL}

All chemicals used in this work were either of Anal $\mathrm{R}$ grade or chemically pure grade.
The Quinazoline-2-thione-4-one (QTH) ${ }^{4}$ precursor complexes, $\left[\mathrm{RuCl}_{2}\left(\mathrm{P}_{\phi_{3}}\right)_{4}\right]^{5},\left[\mathrm{RuHCl}(\mathrm{CO})\left(\mathrm{P} \phi_{3}\right)_{3}\right]^{6}$, $\left[\mathrm{RuHCl}(\mathrm{CO})\left(\mathrm{As}_{3}\right)_{3}\right]^{7},\left[\mathrm{RuHCl}(\mathrm{CO})\left(\mathrm{P} \phi_{3}\right)_{2}(\mathrm{P} \phi)\right]^{8}$, $\left[\mathrm{RuCl}_{3}(\mathrm{P} \phi)_{3}\right]^{9},\left[\mathrm{RuBr}_{3}\left(\mathrm{P}_{3}\right)_{3}\right]^{10}$ and $\left[\mathrm{RuCl}_{3}\left(\mathrm{As}_{3}\right)_{3}\right)^{11}$ were prepared by reported literature methods.<smiles>O=c1[nH]c(=S)[nH]c2ccccc12</smiles>

Structure I: 
Preparation of new ruthenium (II) complexes

All new ruthenium (II) complexes of composition $\left[\mathrm{RuCl}(\mathrm{CO})\left(\mathrm{E}_{\phi_{3}}\right)_{2}(\mathrm{QT})\right](\mathrm{E}=\mathrm{As} / \mathrm{P})$ were prepared by the ligand substitution in benzene using precursor complexes and ligand reported in our previous method. ${ }^{12}$ The other ruthenium (II) complex of composition $\left[\mathrm{Ru}\left(\mathrm{P}_{\phi_{3}}\right)_{2}(\mathrm{QT})_{2}\right]$ was prepared by direct reaction of $\left[\mathrm{RuCl}_{2}\left(\mathrm{P}_{3}\right)_{4}\right]$ with ligand $(\mathrm{QTH})$ following our previous method. ${ }^{13}$

The analysis of $\mathrm{C}, \mathrm{H}$ and $\mathrm{N}$ were performed at CDRI, Lucknow, India. The IR spectra of ligand and complexes were recorded on a Perkin-Elmer Model-577 Spectrophotometer in the range of 4000$200 \mathrm{~cm}^{-1}$ as $\mathrm{KBr}$ pillets. The magnetic measurements were made on a Gouy balance and diamagnetic corrections for the ligand molecule were applied. Electronic spectra were recorded with Beckmann DU-6 spectrophotometer. The molar conductance of complexes $\left(10^{-3} \mathrm{M}\right)$ were measured in DMF using Wiss-Wekstatter Weighein obb type LBR conductivity meter. The ${ }^{1} \mathrm{H}$ NMR spectra were recorded on Bruker $400 \mathrm{MHz}$ using TMS as reference.

\section{RESULTS AND DISCUSSION}

The ligand directly reacts with precursors and yielded solid products without change in oxidation state of ruthenium :

(ii)

$$
\left[\mathrm{RuCl}_{2}\left(\mathrm{P} \phi_{3}\right)_{4}\right] \mid+2 \mathrm{QTH} \underset{\text { Reflux, } 4-5 \mathrm{~h}}{\stackrel{\mathrm{C}_{6} \mathrm{H}_{6} / \mathrm{MeOH}}{\longrightarrow}}\left[\mathrm{Ru}\left(\mathrm{P} \phi_{3}\right)_{2}(\mathrm{QT})_{2}\right]+2 \mathrm{HCl}+2 \mathrm{P} \phi_{3}
$$

$$
\begin{gathered}
{\left[\operatorname{RuX}_{3}\left(\mathrm{E}_{3}\right)_{3}\right]+\mathrm{QTH} \quad \stackrel{\mathrm{C}_{6} \mathrm{H}_{6} / \mathrm{MeOH}}{\operatorname{Reflux}, 4 \mathrm{~h}}\left[\mathrm{RuX}_{2}\left(\mathrm{E} \phi_{3}\right)_{2}(\mathrm{QT})\right]+\mathrm{HX}+\mathrm{E} \phi_{3}} \\
(\mathrm{E}=\mathrm{P} / \mathrm{As} ; \mathrm{X}=\mathrm{Cl} / \mathrm{Br})
\end{gathered}
$$

$$
\left[\mathrm{RuHCl}(\mathrm{CO})\left(\mathrm{E} \phi_{3}\right)_{3}\right]+\mathrm{QTH} \underset{\text { Reflux, } 4 \mathrm{~h}}{\stackrel{\mathrm{C}_{6} \mathrm{H}_{6} / \mathrm{MeOH}}{\longrightarrow}}\left[\operatorname{RuCl}(\mathrm{CO})\left(\mathrm{E} \phi_{3}\right)_{2}(\mathrm{QT})\right]+\mathrm{H}_{2}+\mathrm{E} \phi_{3}
$$

$(E=A s / P)$

The analytical data is consistent with the proposed stoichiometeries of the complexes. In all the above reactions, the thioamide ligand behaves as mononegative bidentate ligand. All isolated solid products are air stable in the solid state at room temperature and are non-hygroscopic in nature. All synthesized complexes are soluble in DMF, DMSO and acetonitrile producing intense coloured solution. The molar conductance in DMF $\left(10^{-3} \mathrm{M}\right)$ are found in the range of $10.16-15.5 \Lambda^{-1} \mathrm{~cm}^{2} \mathrm{~mol}^{-1}$ indicating their non-electrolytic nature. ${ }^{15}$ The chloride or bromide ion in corresponding complexes are present in the inner sphere and coordinated nature.

\section{Magnetic Moment and Electronic Spectra}

All ruthenium (II) chelates are diamagnetic indicating the ground state ${ }^{1} \mathrm{~A}_{1 \mathrm{~g}}$ arising from $\mathrm{T}_{2 \mathrm{~g}}{ }^{6} \mathrm{eg}^{0}$ configuration in octahedral structure. ${ }^{16}$ The excited state corresponding to the $\mathrm{T}_{2 g}{ }^{5} \mathrm{eg}^{1}$ configuration are ${ }^{3} \mathrm{~T}_{1 \mathrm{~g}},{ }^{3} \mathrm{~T}_{2 \mathrm{~g}},{ }^{1} \mathrm{~T}_{1 \mathrm{~g}}$ and ${ }^{1} \mathrm{~T}_{2 \mathrm{~g}}$. Hence, four bands corresponding to the transition, ${ }^{1} \mathrm{~A}_{1 \mathrm{~g}} \rightarrow{ }^{3} \mathrm{~T}_{1 \mathrm{~g}},{ }^{1} \mathrm{~A}_{1 \mathrm{~g}}$ $\rightarrow{ }^{3} \mathrm{~T}_{2 \mathrm{~g}},{ }^{1} \mathrm{~A}_{1 \mathrm{~g}} \rightarrow{ }^{1} \mathrm{~T}_{1 \mathrm{~g}}$ and ${ }^{1} \mathrm{~A}_{1 \mathrm{~g}} \rightarrow{ }^{1} \mathrm{~T}_{2 \mathrm{~g}}$ are possible in order of increasing energy. The electronic spectra $\left[\mathrm{RuCl}(\mathrm{CO})\left(\mathrm{E}_{3}\right)_{2}(\mathrm{QT})\right](\mathrm{E}=\mathrm{P} / \mathrm{As})$ exhibits bands at $21740 \mathrm{~cm}^{-1}\left({ }^{1} \mathrm{~A}_{1 \mathrm{~g}}{ }^{1} \mathrm{~T}_{1 \mathrm{~g}}\right), 23255 \mathrm{~cm}^{-1}\left(\mathrm{~T}_{2 \mathrm{~g}} \rightarrow \pi^{*}\right.$, LMCT), $29850 \mathrm{~cm}^{-1}\left(\mathrm{n} \rightarrow \pi^{\star}\right.$, LC) and $33890 \mathrm{~cm}^{-1}$ $\left(p \rightarrow \pi^{*}, L C\right)$ and $33890 \mathrm{~cm}^{-1}\left(\pi \rightarrow \pi^{*}, \mathrm{LC}\right)$ similar to those observed for the low-spin $\left(\mathrm{Ru}^{++}, \mathrm{d}^{6}\right)$ complexes containing N,S-chelating thioamide, $\mathrm{P}_{3}$ or $\mathrm{As}_{3}$ and chloride ligands. ${ }^{17-19}$

The magnetic moment of $\left[\mathrm{RuCl}_{2}\left(\mathrm{E}_{3}\right)_{2}(\mathrm{QT})\right]$ $(E=P / A s)$ chelates are found between 1.85-1.95 $\mathrm{BM}$ corresponding to one unpaired electron in $\mathrm{T}_{29} 5$ $\left(\mathrm{Ru}^{+++}\right)$in octahedral environment. ${ }^{20}$ The ground state of Ru (III) in octahedral environment is ${ }^{2} \mathrm{~T}_{29}$ arising from $\mathrm{T}_{29}{ }^{5} \mathrm{eg}^{0}$ configuration. Hence, two bands corresponding to ${ }^{2} \mathrm{~T}_{2 \mathrm{~g}} \rightarrow{ }^{2} \mathrm{~A}_{2 \mathrm{~g}}$ and ${ }^{2} \mathrm{~T}_{2 \mathrm{~g}} \rightarrow{ }^{2} \mathrm{~T}_{1 \mathrm{~g}}$ are possible. The complexes display bands at 15870 $\mathrm{cm}^{-1}\left({ }^{2} \mathrm{~T}_{2 \mathrm{~g}} \rightarrow{ }^{2} \mathrm{~A}_{2 \mathrm{~g}}\right), 21970 \mathrm{~cm}^{-1}$ (LMCT) and 33115 


\section{Analysis}

S. No1: $\quad\left[\mathrm{RuCl}(\mathrm{CO})\left(\mathrm{P} \phi_{3}\right)_{2}(\mathrm{QT})\right]$ (yellow)

S. No. 2 : $\quad\left[\mathrm{RuCl}(\mathrm{CO})\left(\mathrm{As}_{3}\right)_{2}(\mathrm{QT})\right]$ (yellow) :

S. No. 3 : $\quad\left[\mathrm{RuCl}(\mathrm{CO})\left(\mathrm{P} \phi_{3}\right)(\mathrm{Py})(\mathrm{QT})\right]$ (yellow)

S. No. $4: \quad\left[R u\left(P \phi_{3}\right)_{2}(\mathrm{QT})_{2}\right]$ (yellowish brown)

Preparation of new ruthenium (III) complexes

Calculated (\%) for $\mathrm{RuC}_{45} \mathrm{H}_{35} \mathrm{~N}_{2} \mathrm{O}_{2} \mathrm{P}_{2} \mathrm{SCl}$ (865.5) : $\mathrm{C}=$ 62.39; $\mathrm{H}=4.04 ; \mathrm{N}=3.23 ; \mathrm{Cl}=4.10 ; \mathrm{Ru}=11.66$; Found $(\%): \mathrm{C}=62.42 ; \mathrm{H}=4.10 ; \mathrm{N}=3.33 ; \mathrm{Cl}=4.21 ; \mathrm{Ru}=$ 11.55 ;

Calculated (\%) for $\mathrm{RuC}_{45} \mathrm{H}_{35} \mathrm{~N}_{2} \mathrm{O}_{2} \mathrm{As}{ }_{2} \mathrm{SCl}$ (953.5) : $\mathrm{C}=$ 56.63; $\mathrm{H}=3.74 ; \mathrm{N}=2.99 ; \mathrm{Cl}=3.72 ; \mathrm{Ru}=10.59$; Found $(\%): \mathrm{C}=56.11 ; \mathrm{H}=3.77 ; \mathrm{N}=3.01 ; \mathrm{Cl}=80 ; \mathrm{Ru}=10.32$; Calculated (\%) for $\mathrm{RuC}_{32} \mathrm{H}_{25} \mathrm{~N}_{3} \mathrm{O}_{2} \mathrm{PSCl}(682.5): \mathrm{C}=$ 56.26; $\mathrm{H}=3.66 ; \mathrm{N}=6.15 ; \mathrm{Cl}=5.20 ; \mathrm{Ru}=14.79$; Found $(\%): C=56.20 ; \mathrm{H}=3.70 ; \mathrm{N}=6.01 ; \mathrm{Cl}=5.33 ; \mathrm{Ru}=14.80$;

Calculated (\%) for $\mathrm{RuC}_{52} \mathrm{H}_{40} \mathrm{~N}_{4} \mathrm{O}_{2} \mathrm{P}_{2} \mathrm{~S}_{2}(979): \mathrm{C}=63.73$; $\mathrm{H}=4.08 ; \mathrm{N}=5.72 ; \mathrm{Ru}=10.31 ;$ Found $(\%): \mathrm{C}=63.77$; $H=4.11 ; N=5.70 ; R u=10.42$;

All ruthenium complexes were prepared by following our previous method reported in literature. ${ }^{14}$

S. No. $5 \quad\left[\mathrm{RuCl} 2\left(\mathrm{P} \phi_{3}\right)_{2}(\mathrm{QT})\right]$ (Brown)

S. No. 6 : $\quad\left[\operatorname{RuCl}_{2}\left(\mathrm{As} \phi_{3}\right)_{2}(\mathrm{QT})\right.$ (Brown)

S. No. $7: \quad\left[\operatorname{RuBr}_{2}\left(\mathrm{P} \phi_{3}\right)_{2}(\mathrm{QT})\right]$ (Brown)
Calculated (\%) for $\mathrm{RuC}_{44} \mathrm{H}_{35} \mathrm{~N}_{2} \mathrm{OSP}_{2} \mathrm{Cl}_{2}$ (873): $\mathrm{C}=60.48$; $\mathrm{H}=4.00 ; \mathrm{N}=3.20 ; \mathrm{Ru}=11.56$; Found $(\%): \mathrm{C}=60.47 ; \mathrm{H}$ $=4.11 ; \mathrm{N}=3.21 ; \mathrm{Ru}=11.66$;

Calculated (\%) for $\mathrm{RuC}_{44} \mathrm{H}_{35} \mathrm{~N}_{2} \mathrm{OAs}_{2} \mathrm{Cl}_{2}$ (961): $\mathrm{C}=$ $54.94 ; \mathrm{H}=3.64 ; \mathrm{N}=2.91 ; \mathrm{Cl}=7.38 ; \quad \mathrm{Ru}=10.50 ;$ Found (\%) : $\mathrm{C}=55.01 ; \mathrm{H}=3.66 ; \mathrm{N}=3.01 ; \mathrm{Cl}=7.48 ; \mathrm{Ru}=10.55$; Calculated (\%) for $\mathrm{RuC}_{44} \mathrm{H}_{35} \mathrm{~N}_{2} \mathrm{OP}_{2} \mathrm{Br}_{2}(962): \mathrm{C}=54.88$; $\mathrm{H}=3.62 ; \mathrm{N}=2.91 ; \mathrm{Ru}=10.49 ;$ Found $(\%): \mathrm{C}=54.98 ; \mathrm{H}$ $=3.71 ; \mathrm{N}=3.01 ; \mathrm{Ru}=10.50$

Table 1: Major IR Spectral bands $\left(\mathrm{cm}^{-1}\right)$ of ligand (QTH) and complexes

\begin{tabular}{|c|c|c|c|c|c|c|}
\hline \multirow[t]{2}{*}{ Compounds } & \multirow[t]{2}{*}{$v \mathbf{C} \equiv \mathbf{O}$} & \multicolumn{4}{|c|}{ Thioamide Bands } & \multirow{2}{*}{$\begin{array}{l}\text { vRu-N/ } \\
\text { vRu-S }\end{array}$} \\
\hline & & Band I & Band II & Band III & Band IV & \\
\hline QTH (ligand) & - & $1530(\mathrm{~s})$ & $1295(\mathrm{~m})$ & $960(\mathrm{~m})$ & $790(\mathrm{~m})$ & $-(-)$ \\
\hline$\left[\mathrm{RuCl}(\mathrm{CO})\left(\mathrm{P} \phi_{3}\right)_{2}(\mathrm{QT})\right]$ & $1565(\mathrm{~m})$ & $\begin{array}{l}1535 \mathrm{~m} \\
1510 \mathrm{~m}\end{array}$ & $1310 \mathrm{~m}$ & $955 \mathrm{w}$ & $780 \mathrm{w}$ & $\begin{array}{l}455 \mathrm{~m} \\
(420 \mathrm{w})\end{array}$ \\
\hline$\left.\left[\mathrm{RuCl}(\mathrm{CO})\left(\mathrm{As}_{3}\right)_{2}\right)_{2}(\mathrm{QT})\right]$ & $1566(\mathrm{~s})$ & $\begin{array}{l}1535 \mathrm{~m} \\
1515 \mathrm{~m}\end{array}$ & $1315 \mathrm{~m}$ & $950 w$ & $780 w$ & $\begin{array}{l}465 \mathrm{~m} \\
(425 \mathrm{w})\end{array}$ \\
\hline$\left[\mathrm{RuCl}(\mathrm{CO})\left(\mathrm{P}_{3}\right)(\mathrm{Py})(\mathrm{QT})\right]$ & $1570 \mathrm{~ms}$ & $\begin{array}{l}1530 \mathrm{~m} \\
1515 \mathrm{~m}\end{array}$ & $1315 \mathrm{~m}$ & $950 w$ & $780 w$ & $\begin{array}{l}470 \mathrm{~m} \\
(420 \mathrm{w})\end{array}$ \\
\hline$\left[\mathrm{RuCl}_{2}\left(\mathrm{P}_{3}\right)_{2}(\mathrm{QT})\right]$ & - & $\begin{array}{l}1530 \mathrm{~m} \\
1510 \mathrm{~m}\end{array}$ & $1310 \mathrm{~ms}$ & $945 \mathrm{vw}$ & $780 w$ & $\begin{array}{l}465 \mathrm{~m} \\
(425 \mathrm{w})\end{array}$ \\
\hline$\left[\operatorname{RuCl}\left(\operatorname{As}_{3}\right)_{2}(\mathrm{QT})\right]$ & - & $\begin{array}{l}1535 \mathrm{~m} \\
1515 \mathrm{~m}\end{array}$ & $1310 \mathrm{~m}$ & $945 \mathrm{vw}$ & $785 w$ & $\begin{array}{l}460 \mathrm{~m} \\
(410 \mathrm{~m})\end{array}$ \\
\hline$\left[\operatorname{RuBr}_{2}\left(\mathrm{P}_{\phi_{3}}\right)_{2}(\mathrm{QT})\right]$ & - & $\begin{array}{l}1535 \mathrm{~m} \\
1510 \mathrm{~m}\end{array}$ & $1315 \mathrm{~m}$ & $950 w$ & $780 w$ & $\begin{array}{l}455 \mathrm{~m} \\
(415 \mathrm{w})\end{array}$ \\
\hline$\left[R u\left(P \phi_{3}\right)_{2}(\mathrm{QT})_{2}\right]$ & - & $\begin{array}{l}1530 m \\
1515 m\end{array}$ & $1316 \mathrm{~m}$ & $950 \mathrm{w}$ & $775 w$ & $\begin{array}{l}465 \mathrm{~m} \\
(420 \mathrm{w})\end{array}$ \\
\hline
\end{tabular}


$\left(\pi \rightarrow \pi^{*}\right)$ which indicates octahedral environment around ruthenium (III) ion and consistent with the other ruthenium (III) octahedral complexes. ${ }^{21}$

\section{IR Spectra}

A comparison of the IR spectra (table 1) of the ligand (QTH) and ruthenium (II \& III) complexes brings out the following facts to light:

(i) The medium broad $\mathrm{vN}-\mathrm{H}$ bands of the ligand at 3446 and $3350 \mathrm{~cm}^{-1}$ are severely affected on coordination. The $3446 \mathrm{~cm}^{-1}$ band almost disappears indicating displacement of $\mathrm{N}-\mathrm{H}$ hydrogen by means of $R u(I I) / R u(I I I)$ ion and formation of $R u(I I)-N /$ $\mathrm{Ru}(\mathrm{III})-\mathrm{N}$ bond. While the $3350 \mathrm{~cm}^{-1}$ band shift to lower frequency and gets split. (ii) The $\mathrm{vC}=\mathrm{O}$ band of the ligand at $1710 \mathrm{~cm}^{-1}$ is found to be almost at the same place in the spectra of complexes indicating absence of bonding through carbony oxygen atom. ${ }^{22}$ (iii) All carbonyl complexes of ruthenium (II) display a new strong band in the region 1955-1960 $\mathrm{cm}^{-1}$ which is attributed due to terminally coordinated carbonyl group and is observed at higher frequency than in the precursor complexes. ${ }^{23}$ (iv) Thioamide bands $^{24-26} \mathrm{I}, \mathrm{II}, \mathrm{III}$ and IV are observed at 1530 (s), $1295(\mathrm{~m}), 960(\mathrm{~m})$ and $790(\mathrm{~m}) \mathrm{cm}^{-1}$ in the spectrum of ligand (QTH). Band I splits, Band II blue shift to higher frequency, while band III and band IV red shift with reduction in intensity. (table 1) on complexation indicating simultaneous bonding with $\mathrm{N}$ and $\mathrm{S}$ atoms of QTH considering our previous observations. ${ }^{27-29}$ (v) New bands around 535, 685, 740 and $1560 \mathrm{~cm}^{-1}$ due to coordinated $\mathrm{As}_{3}$ and around 540, 690, 740 and $1535 \mathrm{~cm}^{-1}$ due to coordinated $\mathrm{P} \phi_{3}$ molecule are in agreement with previous literature. ${ }^{30-32}$ (vi) The single $\mathrm{Ru}(\mathrm{III})-\mathrm{Cl}$ stretching mode in $\left[\mathrm{RuCl}_{2}\left(\mathrm{E}_{3}\right)_{2}\right.$ (QT)] indicates two mutual chlorine atoms are at Trans-position in octahedral structure (Str. III).

Thus, the thioamide ligand acts as $\mathrm{N}$, $\mathrm{S}$-chelating mononegative bidentate nature in octahedral structure.

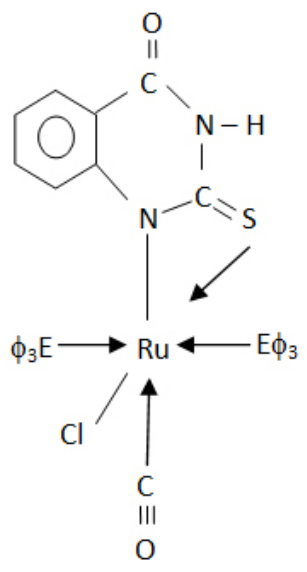

Structure 1 \& 2 ( $E=$ P/As) (Str. II)

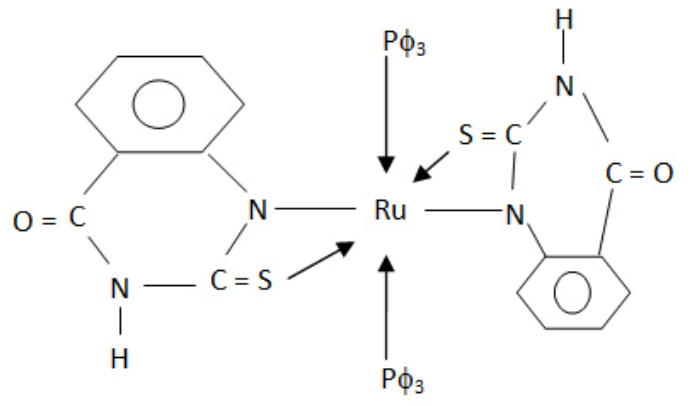

Structure $4(E=P / A s)$

(Str. III)<smiles>[X]C1([R16])[SH]=C[N+]1([X])CCC</smiles>

Structure 5, 6 \& 7

( $\mathrm{X}=\mathrm{Cl} / \mathrm{Br} ; \mathrm{E}=\mathrm{P} / \mathrm{As}$ )

(Str. IV) 


\section{${ }^{1} \mathrm{H}$ NMR Spectra}

${ }^{1} \mathrm{H}$ NMR spectra of ligand and some complexes (SI. No. 1, 2 \& 3) were recorded in $\mathrm{CDCl}_{3} /$ TMS to substantiate further metal-ligand bonding. The aromatic protons signals are observed at $\delta 7.8$ - 8.6 PPM and the aromatic proton at position -5 is deshielded by carbonyl oxygen so the extreme signal at $\delta 8.3$ PPM is considered to be due to this proton. The imino protons of the ligand observed at $\delta 3.2-$ 3.6 PPM found to be absent in complexes indicating deprotonation of imino group. The ${ }^{1} \mathrm{H}$ NMR spectra of complexes show a multiplet around 66.2-7.7 PPM which is assigned to aromatic protons of $\mathrm{P}_{\phi_{3}} / \mathrm{As}_{3}{ }_{3}{ }^{33}$ The resonances in the region $\delta 7.68$ PPM, 8 8.2 PPM and $\delta$ 8.8 PPM assignable to the protons of Pyridine ligand along with the resonances due to aromatic protons in complexes. ${ }^{34}$

Thus, on the basis of physico-chemical, conductometric, magnetic, UV-vis, IR and ${ }^{1} \mathrm{H}$ NMR data octahedral structure of both $\mathrm{Ru}(\mathrm{II})$ and $\mathrm{Ru}$ (III) complexes may be reasonably assigned.

\section{ACKNOWLEDGEMENTS}

One of the authors (KVG) gratefully acknowledge UGC (New Delhi) to award Junior Research Fellowship (JRF, NET) and thanks to Principal, Dr. R.K. Verma, College of Commerce (M.U.), Patna-800020 for necessary facilities.

\section{REFERENCES}

1. Singh B., Rukhaiyar M.M.P. and Sinha R.J., J. Inorg. Nucl. Chem. 39: 29 (1977).

2. Pandey R.N., Sinha Anil Kumar, Sharma R.N. and Ranjan R.K., Asian J. Chem. 6(2): 246 (1994).

3. Pandey R.N., Sharma R.N., Choudhary L.M. Roy and Sharma Pramila, J. Indian Chem. Soc. 69: 719 (1992).

4. Dave G.R., J. Indian Chem. Soc. 37: 695 (1960).

5. Stephenson T.A. and Wilkonson G., J. Inorg. Nucl. Chem. 28: 945 (1966).

6. Ahmed N., Levision J.J., Robinson S.D. and Uttley M.F., Inorg. Synth, 15: 48 (1974).

7. Delgade R.A.S., Lee W.Y., Choi S.R., Cho Y. and Jan M.Y., Transition Met. Chem. 16: 241 (1991).

8. Balasubramanian K.P., Manivannan S. and Chinnusamy V., J. Ultra Chem. 4: 15 (2008).

9. Chatt J., Leigh G.J., Mingos D.M.P. and Pask R.J., J. Chem. Soc. A: 2636 (1968).

10. Natarajan K., Poddar R.K. and Agarwala U., J. Inorg. Nucl. Chem. 39: 431 (1997).

11. Poddar R.K., Khullar I.P. and Agarwala U., J. Inorg. Nucl. Chem. Lett. 10: 221 (1974).

12. Pandey R.N., Bala Renu and Sinha Anil Kumar, Oriental J. Chem. 27(1): 293 (2011).

13. Pandey R.N., Pandey Prashasti and Sharma R.N., Acta Ciencia Indica,35C(2): 217 (2009).
14. Pandey R.N., Nag A.K. and Sharma D.K., Orient. J. Chem. 28(4): 1809 (2012).

15. Geary W.J., Coord. Chem. Rev. 7: 81 (1971).

16. Pandiarajan D. and Ramesh R., J. Organomet. Chem. 723: 26 (2013).

17. Raja M. Ulaganatha and Ramesh R., J. Organomet. Chem. 699: 5 (2012).

18. Murali S., Sastri C.V. and Maiya B.G., Proc. Indian Acad. Sci (Chem. Sci) 114(4): 403 (2002).

19. Prabhu R.N. and Ramesh R., J. Royal Soc. Chem. 2: 4515 (2012).

20. Raja N. and Ramesh R., Spectrochimica Acta, Part A, 75: 713 (2010).

21. Samanta R., Mandal B., Munshi P. and Lahiri G.K., J. Chem. Soc. Dalton Trans, 1827 (2001).

22. Pandey R.N. and Das J.N., J. Indian Chem. Soc. 71: 187 (1994).

23. Chandra M., Sahay A.N., Pandey D.S., Puerta M.C. and Valerga Pedro, J. Organomet. Chem. 648: 39 (2002).

24. Rao C.N.R. and Venkataraghavan R., Spectrochim. Acta, 18: 541 (1962).

25. Rao C.N.R., Venkataraghavan R. and Kasturi T.R., Can. J. Chem. 42: 36 (1964).

26. Suzuki I., Bull. Chem. Soc. (Japan) 35: 1286, 1449, 1456 (1962).

27. Singh B., Pandey R.N., Sharma D.K., Sharma 
U.S. Pd. and Bhanu Uday, Indian J. Chem, 20A: 1097 (1982).

28. Pandey R.N., Sharma Pramila and Kumar Manoj, J. Ultra Chem. 9(2): 279 (2013).

29. Pandey R.N., Aanand A., Singh R.K. and Kumar A., Asian J. Chem. 22(7): 5601 (2010).

30. Cao M., DO L.V., Hofmann N.W., Kwan M.L., Little J.K., Gilvray J.M. Mc, Morris C.B., Soderborg B.C. and Weirzbicki,
Organometallics, 20: 2270 (2001).

31. Kumar K.N. and Ramesh R., Polyhedron, 24: 1885 (2005).

32. Shobalake K., Postmus C., Ferraro J.R. and Nakamoto K., Appl. Spectrosc. 23: 12 (1969).

33. Balasubramian K.P., Raju V.V. and Chinnusamy V., J. Indian Chem. Soc. 86: 570 (2009).

34. Sisodiya S.S., Sahay A.N. and Pandey D.S., Indian J. Chem. 39A: 454 (2000). 